\title{
Prevalence of diseases in commercial chickens at sylhet division of Bangladesh
}

\begin{abstract}
The study was undertaken to determine the prevalence diseases in commercial chickens in Sylhet region of Bangladesh. Among the diseases prevalence of infectious bursal disease (IBD) is higher (22\%) followed by colibacillosis (14.03\%), Newcastle disease (ND) (13.84\%), salmonellosis (12.18\%), chronic respiratory disease (CRD) $(11.66 \%)$, coccidiosis $(7.87 \%)$, aspergillosis $(7.2 \%)$, omphalitis $(5.31 \%)$, fowl cholera $(2.70 \%)$, fowl pox $(0.28 \%)$, nutritional deficiency $(0.23 \%)$, lymphoid leucosis $(0.14 \%)$ and some mixed infections like salmonellosis plus E. coli (1.14\%), IBD plus coccidiosis $(0.71 \%)$, ND plus colibacillosis $(0.71 \%)$. According to the age groups, disease prevalence was recorded as $33.41 \%$ among the age group of $21-35$ days followed by 8 -20days age group (21\%), 61- above days age group (17.49\%), 36-60 days age group (15.92\%) and $0-8$ days age group $(12.18 \%)$ of commercial chickens. The distribution and proportionate occurrence of diseases in chickens of Bangladesh indicated that the diseases frequently occurred in summer season $(39.85 \%)$ followed by winter $(32.80 \%)$ and rainy season $(27.35 \%)$.
\end{abstract}

Keywords: disease prevalence, commercial chicken, Bangladesh
Volume I Issue 5 - 2015

\author{
Badruzzaman ATM,' Monira Noor,' \\ Mohammad Al Mamun, ' Asmaul Husna, ${ }^{2}$ Kazi \\ Mehetazul Islam, ${ }^{3}$ Masudur Rahman Md' \\ 'Department of Pathology, Sylhet Agricultural University, \\ Bangladesh. \\ ${ }^{2}$ Faculty of Veterinary and Animal Science, Sylhet Agricultural \\ University, Bangladesh. \\ ${ }^{3}$ Department of Parasitology, Sylhet Agricultural University, \\ Bangladesh.
}

\begin{abstract}
Correspondence: Md. Masudur Rahman, Department of Pathology, Faculty of Veterinary and Animal Science, Sylhet Agricultural University, Sylhet 3100, Bangladesh, Fax +88-082 I 761980, Tel +88-0821-761002(201),

Email rahmanmm.dpp@sau.ac.bd or mmrahman.sau@gmail.com
\end{abstract}

Received: October 30, 2015 | Published: December 21, 2015
Abbreviations: ND, newcastle disease; CRD, chronic respiratory disease; FDIL, field disease investigation laboratory; CDIL, central disease investigation laboratory; IBD, infectious bursal disease

\section{Introduction}

Poultry industry in Bangladesh plays a vital role in the rural socioeconomic system by contributing significantly on economic growth and simultaneously creating numerous employment opportunities. Chicken meat is also relatively cheap and affordable source of animal protein. ${ }^{1}$ According to WHO-FAO joint survey, meat consumption per head in Bangladesh is $15.23 \mathrm{~kg}$ per year and poultry contributes $35.25 \%$ of total meat supply. ${ }^{2}$ Traditionally in Bangladesh, poultry rearing is one of the most important sources of income for rural women especially for landless and marginal farmers. ${ }^{3}$ From last few years commercial poultry farming has been developing very rapidly but several factors reduce the growth rate of this sector and raise mortality of chickens. It is well known that poultry diseases are the major constraints for developing the poultry industry. ${ }^{4}$ Poultry farmers face a wide range of diseases, which reduce the optimal productivity of the flock. On an average 30\% poultry birds die annually in Bangladesh due to outbreak of several diseases. ${ }^{5,6}$ Diseases in broiler significantly affect the productivity and health status ${ }^{7}$ and many of them also have public health importance. ${ }^{8,9}$

The prevalence of diseases in a particular area depends on several factors like geographical condition, management practices by the farmer, immunization status of the farm, quality of the chicks, biosecurity status of farm and hatcheries etc. Age of the chicken and weather of a particular area are also important factors which are related to the disease prevalence. ${ }^{10}$ Geographically Sylhet is located at $24.8917^{\circ} \mathrm{N} 91.8833^{\circ} \mathrm{E}$, in the north eastern region of Bangladesh which has a number of topographical features like rivers, hills and hillocks, haors which made it quite different from the rest parts of the country. Poultry industry is not so developed in this region compared to other poultry rich zones of Bangladesh like Kishoregonj, Narsindi, Gazipur, Comilla etc. However, it is developing very quickly in this region now a days based on demands. Therefore, the present study was undertaken to determine the prevalence of diseases in commercial chickens at Sylhet division of Bangladesh. Age related disease prevalence and seasonal influence on disease prevalence in commercial chickens at this particular area was also determined. The results of the current study will provide an overall scenario of disease prevalence in commercial chickens at Sylhet region of Bangladesh. The findings may assist researchers or poultry consultants to design and implement priority based research on specific disease and to take efficient control strategies against the diseases.

\section{Materials and methods}

The study was conducted to determine the prevalence of diseases in commercial chickens at Sylhet division of Bangladesh during the period from June 2013 to May 2015 at the Field Disease Investigation Laboratory (FDIL), Sylhet. A total of 2110 either dead or sick commercial chickens were brought to the selected laboratory from different poultry farms located at different areas of Sylhet division to diagnose the existing diseases. The diagnosis of different diseases was done based on the clinical history of the flock, age of affected birds, clinical signs and symptoms, gross and microscopic examinations. ${ }^{11,12}$ 
Specific test kits were primarily used for the diagnosis of diseases. In some cases, diseases were confirmed by the isolation and identification of causal agents. Suspected materials were incubated in McConkey agar, Sabouraud dextrose agar, blood agar and cooked meat media for growth of Salmonella, E.coli, Aspergillus, Pasteurella and Clostridium respectively. The growth obtained was identified by various biochemical and sugar fermentation tests following methods described by Harrigan. ${ }^{13}$ For viral disease diagnosis, several types of serological tests were performed at the Laboratory of Microbiology and Immunology, Sylhet Agricultural University, Sylhet, Bangladesh. In some complicated cases suspected specimens were sent to the Central Disease Investigation Laboratory (CDIL) at Dhaka, Bangladesh for final confirmation. The influences of season and age on the occurrence of diseases were also analyzed. Accordingly, data were analyzed into four age groups: 0-07days, 8-20days, 21-35days, $36-60$ and 61 to above days. On the basis of climatic conditions the year was divided into three seasons namely summer, rainy and winte. Summer season was considered from March to June, rainy season from July to October and winter was considered from November to February.

\section{Results and discussion}

The overall prevalence of different infectious and non-infectious diseases in commercial chickens at Sylhet division was shown in Table 1. According to our results, prevalence of infectious bursal disease (IBD) is higher (22\%) followed by colibacillosis (14.03\%), Newcastle disease (ND) (13.84\%), salmonellosis $(12.18 \%)$, chronic respiratory disease (CRD) $(11.66 \%)$, coccidiosis $(7.87 \%)$, aspergillosis $(7.2 \%)$, omphalitis $(5.31 \%)$, fowl cholera $(2.70 \%)$, fowl pox $(0.28 \%)$, nutritional deficiency $(0.23 \%)$, lymphoid leucosis $(0.14 \%)$ and some mixed infections like salmonellosis plus E. coli $(1.14 \%)$, IBD plus coccidiosis $(0.71 \%)$, ND plus colibacillosis $(0.71 \%)$. Prevalence of diseases according to the age group of chickens and seasonal prevalence of diseases were shown in Table $2 \&$ Table 3 respectively. As shown in Table 2, disease prevalence was recorded as $33.41 \%$ among the age group of 21-35days followed by 8-20days age group $(21 \%), 61$ - above days age group $(17.49 \%), 36-60$ days age group $(15.92 \%)$ and $0-8$ days age group (12.18\%) of commercial chickens. According to Table 3, the diseases frequently occurred in summer season $(39.85 \%)$ followed by winter $(32.80 \%)$ and rainy season $(27.35 \%)$.

The present study revealed 22\% of IBD in Sylhet region that was higher than from Dhaka and Mymensingh where it was reported as $10.99 \%, 16.0 \%$ and $19.16 \%$ cases of IBD, respectively. ${ }^{14-16}$ This may be due to land topographic variation. In Sylhet division IBD was one of the most prevalent diseases and previously it was recorded as $24.26 \%{ }^{17}$ which was higher from the present study. Along with high prevalence of IBD, morbidity rate of IBD was near about $100 \%{ }^{18}$ but mortality was $33 \%{ }^{19}$ to highest $80 \% .^{18,20}$ Most of the IBD affected flocks were recorded as vaccinated. Findings indicated that in most cases vaccination could not protect the birds due to faulty method of vaccination or break of vaccine. There are several factors that are involved in vaccination failure such as vaccine type, storage and handling, level of maternal antibody or administration of vaccine. ${ }^{21}$

In the present investigation, $13.84 \%$ of ND positive cases were found. Occurrence rate of ND in Sylhet district is increasing day by day where occurrence was recorded $6.73 \% .{ }^{17} \mathrm{ND}$ is one of the important viral diseases that cause severe economic losses in every year and incidence of ND may vary from $10.24 \%{ }^{16}$ to $17.20 \% .^{15}$ The present findings would indicate that the reemergence threat of ND in commercial flocks is still increasing. In Sylhet district poultry sector has been developing from last few years. High farm density has a great role in case of immunity breakdown of $\mathrm{ND}^{22}$ resulting increase the ND prevalence in this area. In this study there was no positive report of Avian influenza in Sylhet region although in Dhaka, Gazipur, Mymensingh and Bogra districts Avian influenza is a prevalent disease and it was found that in layer, broiler, native bird and duck prevalence were $12.5 \%, 12.5 \%, 0.0 \%$, and $2.5 \%$, respectively ${ }^{23}$

Apart from viral infection among the other diseases, it was observed that colibacillosis was $14.03 \%$, salmonellosis was $12.18 \%$ which was the higher from other finding of $4.42 \%$ and $5.56 \%$ respectively. ${ }^{24}$ Prevalence of colibacillosis in Mymensingh district was $13.12 \%$ which was lower from the prevalence in Sylhet dristrict. In Sylhet region among all bacterial diseases prevalence of colibacillosis was highest. It is due to expansion of poultry farming in Bangladesh, Colibacillosis has become a widespread problem. ${ }^{17,25-26}$ In Bangladesh prevalence of salmonellosis in layer farm is recorded as $18 \%{ }^{27}$ which is slightly higher from the overall prevalence of the present study. Prevalence of CRD in Sylhet district was $11.66 \%$ which is very similar with the CRD prevalence in Mymensingh district where it was reported $11.55 \% .{ }^{16}$ In the present study, $7.20 \%$ of cases of aspergillosis were reported in Sylhet district, and in Mymensingh region positive cases is $4.20 \%{ }^{16}$ that is lower than Sylhet. Aspergillosis is the major diseases problem in broiler farming in Mymensingh ${ }^{28}$ and it was reported that in this region positive cases was $4.20 \% .{ }^{16}$ This variation may be due to the cold climatic condition of the Sylhet region. In the present study, Coccidiosis constituted $7.87 \%$ of the total cases which is higher than the overall prevalence of Coccidiosis in Bangladesh is $3.08 \%{ }^{16,24}$ Prevalence of Fowl cholera was identified $2.70 \%$ in this study and it has been becoming a more prevalent disease day by day. Previous report showed that prevalence of Fowl cholera in Sylhet is $0.44 \%{ }^{17}$ which is lower to present findings.

Occurrence of diseases has a significant relationship with season. In Pakistan the period during April to June appeared to be comparatively safer for the broilers as low incidence of disease was recorded at this period. ${ }^{29}$ It was found that prevalence of poultry diseases were significantly highest in summer season $(39.85 \%)$ followed by winter $(32.80 \%)$ and rainy season $(27.35 \%)$ (Table 3 ) but several previous report indicated that rainy season is the more prevalent for diseases. ${ }^{30-32}$ Although, disease prevalence in winter is always comparatively lower than other season, some times this season also show highest diseases prevalence. $^{33}$ In summer season $\operatorname{IBD}(8.81 \%)$, CRD $(5.308 \%)$, colibacillosis(5.213\%), $\mathrm{ND}(4.74 \%), \quad$ salmonellosis(4.691\%); in rainy season $\operatorname{IBD}(5.924 \%), \mathrm{ND}(4.976 \%)$, colibacillosis(3.839\%), salmonellosis $(3.744 \%)$, coccidiosis $(2.607 \%)$ and in winter season $\operatorname{IBD}(7.251 \%)$, colibacillosis(4.976\%), CRD(4.218\%), ND(4.123\%), salmonellosis $(3.744 \%)$, aspergillosis $(2.701 \%)$, coccidiosis $(2.654 \%)$ are the subsequently most prevalent diseases among all (Table 3 ).

The highest number of cases were recorded in the age group of $21-35$ days $(33.41 \%)$, followed by 8 -20days age group $(21 \%)$, 61-above days age group (17.49\%), 36-60days age group (15.92\%) and $0-8$ days age group $(12.18 \%)$ of poultry (Table 2 ). Age of the bird had a significant relationship on prevalence and mortality of the disease. Younger chicks are more susceptible to diseases, especially broiler chicks has of age 3-6 weeks were more susceptible to the disease. $^{34,35}$ According to age group, from 0-7age group omphalitis 
$(5.308 \%)$, aspergillosis $(5.165 \%)$, salmonellosis $(1.706 \%)$; from 8 -20age group IBD $(8.957 \%)$, colibacillosis $(3.08 \%)$, salmonellosis $(2.843 \%)$, coccidiosis $(2.085 \%)$, aspergillosis $(2.038 \%)$; from 21 35 age group IBD (11.943\%), ND (8.199\%), colibacillosis (5.355\%), coccidiosis (3.649\%); from 36-60age group colibacillosis $(4.218 \%)$, ND (4.123\%), CRD (2.606\%), salmonellosis (1.706\%), coccidiosis $(1.422 \%)$ and from 61 to above days age group CRD (6.635\%), salmonellosis $(4.171 \%)$, fowl cholera $(2.511 \%)$, colibacillosis $(1.375 \%)$, ND (1.28\%) are the subsequently most prevalent diseases among all (Table 2). In case of CRD birds of all age groups are susceptible to this disease and in this study it was found that adult are more frequently affected by this disease. In Pakistan it was found that young birds are more prone to MG infection than adults. ${ }^{36} \mathrm{ND}$ is highly contagious viral disease of domestic poultry as well as other species of birds regardless of age and sex variation. ${ }^{37}$ In case of semi-scavenging birds, ND affected a significant higher proportion $(18.81 \%)$ of birds older than 60 days of age and proportional mortality due to Fowl pox and IBD is higher in younger. ${ }^{38}$

Table 1 Overall prevalence of diseases in commercial chickens at Sylhet division of Bangladesh during the period from June 2013 to May 2015

\begin{tabular}{lll}
\hline Name of the diseases & No. of identified cases & Prevalence (\%) \\
\hline Newcastle Disease (ND) & 292 & 13.84 \\
Gumboro Disease (IBD) & 464 & 22 \\
Colibacillosis & 296 & 14.03 \\
Salmonellosis & 257 & 12.18 \\
Omphalitis & 112 & 5.31 \\
CRD/ Mycoplasmosis & 246 & 11.66 \\
Aspergillosis & 152 & 7.2 \\
Coccidiosis & 166 & 7.87 \\
Fowl cholera & 57 & 2.7 \\
Lymphoid leucosis & 3 & 0.14 \\
Nutritional deficiency & 5 & 0.23 \\
Fowl pox & 6 & 0.28 \\
ND+E.coli & 15 & 0.71 \\
Salmonella + E. coli & 24 & 1.14 \\
IBD+Coccidia & 15 & 0.71 \\
Total & 2110 & 100 \\
\hline
\end{tabular}

Table 2 Prevalence of diseases in different age groups of commercial chickens at Sylhet division of Bangladesh during the period from June 2013 to May 2015

\begin{tabular}{|c|c|c|c|c|c|c|c|c|c|c|}
\hline \multirow[b]{2}{*}{ Name of Disease } & \multicolumn{10}{|c|}{ Age (Days) } \\
\hline & $\begin{array}{l}0-7 \\
\text { No. of } \\
\text { cases }\end{array}$ & $\begin{array}{l}\text { Prev. } \\
(\%)\end{array}$ & $\begin{array}{l}8 \text { to } 20 \\
\text { No. of } \\
\text { cases }\end{array}$ & $\begin{array}{l}\text { Prev. } \\
(\%)\end{array}$ & $\begin{array}{l}21-35 \\
\text { No. of } \\
\text { cases }\end{array}$ & $\begin{array}{l}\text { Prev. } \\
(\%)\end{array}$ & $\begin{array}{l}\text { 36-60 } \\
\text { No. of } \\
\text { cases }\end{array}$ & $\begin{array}{l}\text { Prev. } \\
(\%)\end{array}$ & $\begin{array}{l}\text { 61-Above } \\
\text { No. of } \\
\text { cases }\end{array}$ & $\begin{array}{l}\text { Prev. } \\
(\%)\end{array}$ \\
\hline $\begin{array}{l}\text { Newcastle Disease } \\
\text { (ND) }\end{array}$ & - & - & 5 & 0.237 & 173 & 8.199 & 87 & 4.123 & 27 & 1.28 \\
\hline $\begin{array}{l}\text { Gumboro Disease } \\
\text { (IBD) }\end{array}$ & - & - & 189 & 8.957 & 252 & 11.943 & 23 & 1.09 & - & - \\
\hline Colibacillosis & - & - & 65 & 3.08 & 113 & 5.355 & 89 & 4.218 & 29 & 1.375 \\
\hline Salmonellosis & 36 & 1.706 & 60 & 2.843 & 37 & 1.753 & 36 & 1.706 & 88 & 4.171 \\
\hline Omphalitis & 112 & 5.308 & - & - & - & - & - & - & - & - \\
\hline $\begin{array}{l}\text { CRD/ } \\
\text { Mycoplasmosis }\end{array}$ & - & - & 17 & 0.806 & 34 & 1.611 & 55 & 2.606 & 140 & 6.635 \\
\hline Aspergillosis & 109 & 5.165 & 43 & 2.038 & - & - & - & - & - & - \\
\hline Coccidiosis & - & - & 44 & 2.085 & 77 & 3.649 & 30 & 1.422 & 15 & 0.711 \\
\hline Fowl cholera & - & - & - & - & - & - & 4 & 0.189 & 53 & 2.511 \\
\hline
\end{tabular}

Table 3 Seasonal prevalence of diseases in commercial chickens at Sylhet division of Bangladesh during the period from June 2013 to May 2015

\begin{tabular}{|c|c|c|c|c|c|c|c|}
\hline Name Of disease & No. Of cases & $\begin{array}{l}\text { Summer } \\
\text { No. Of Cases }\end{array}$ & Prev. (\%) & $\begin{array}{l}\text { Rainy } \\
\text { No. Of cases }\end{array}$ & Prev. (\%) & $\begin{array}{l}\text { Winter } \\
\text { No. Of cases }\end{array}$ & Prev. (\%) \\
\hline Newcastle Disease (ND) & 292 & 100 & 4.74 & 105 & 4.976 & 87 & 4.123 \\
\hline Gumboro Disease (IBD) & 464 & 186 & 8.81 & 125 & 5.924 & 153 & 7.251 \\
\hline Colibacillosis & 296 & 110 & 5.213 & 81 & 3.839 & 105 & 4.976 \\
\hline Salmonellosis & 257 & 99 & 4.691 & 79 & 3.744 & 79 & 3.744 \\
\hline Omphalitis & 112 & 57 & 2.701 & 35 & 1.659 & 20 & 0.948 \\
\hline CRD/ Mycoplasmosis & 246 & 112 & 5.308 & 45 & 2.133 & 89 & 4.218 \\
\hline Aspergillosis & 152 & 66 & 3.128 & 29 & 1.374 & 57 & 2.701 \\
\hline Coccidiosis & 166 & 55 & 2.607 & 55 & 2.607 & 56 & 2.654 \\
\hline Fowl cholera & 57 & 9 & 0.426 & 21 & 0.995 & 27 & 1.28 \\
\hline Lymphoid lucosis & 3 & 3 & 0.142 & - & - & - & - \\
\hline Nutritional deficiency & 5 & 5 & 0.237 & - & - & - & - \\
\hline Fowl pox & 6 & 6 & 0.284 & - & - & - & - \\
\hline $\mathrm{ND}+$ E.coli & 15 & 9 & 0.426 & - & - & 6 & 0.284 \\
\hline Salmonella $+E$. coli & 24 & 18 & 0.853 & 1 & 0.047 & 5 & 0.237 \\
\hline IBD+Coccidia & 15 & 6 & 0.284 & 1 & 0.047 & 8 & 0.379 \\
\hline Total & 2110 & 841 & 39.85 & 577 & 27.35 & 692 & 32.8 \\
\hline
\end{tabular}




\section{Conclusion}

According to the study, most prevalent diseases of commercial chickens at Sylhet division of Bangladesh include infectious bursa disease (IBD), colibacillosis, Newcastle disease (ND), salmonellosis, chronic respiratory disease (CRD), coccidiosis and aspergillosis. It was also found that 21-35days age group of chickens were more susceptible to diseases. Highest disease prevalence was recorded in summer season. The results of the current study provide an overall scenario of disease prevalence in commercial chickens at Sylhet region of Bangladesh. The findings may assist researchers or poultry consultants to design and implement priority based research on specific disease and to take efficient control strategies against the diseases.

\section{Acknowledgements}

The authors are very much thankful to all members of the Field Disease Investigation Laboratory (FDIL), Sylhet, Bangladesh; Laboratory of Microbiology and Immunology, Sylhet Agricultural University, Bangladesh and Central Disease Investigation Laboratory (CDIL), Dhaka, Bangladesh for their cordial cooperation at the time of conducting the research work.

\section{Conflict of interest}

The author declares no conflict of interest.

\section{References}

1. Yami A, Dessie T. The Status of Poultry Research and development. Research Bulletin No. 4, Poultry Commodity Research Program, Debre Zeit Agricultural Research Center, Ethiopia: Alemaya University of Agriculture; 1997

2. Akbar MA, Amin MR, Ali MA, et al. Animal Husbandry-A Business Education for Today and Tomorrow $3^{\text {rd }}$ Annual Conference and Seminar 2013. Bangladesh: Bangladesh Society for Animal Production Education and Research (BSAPER); 2013.

3. Paul DC, Haque MF, Abedin MZ, et al. Participation of women in poultry husbandry in rural Bangladesh. USA: Paper presented in the $10^{\text {th }}$ AFSRE symposium held at Mat Chining University; 1990

4. Karim MJ. Current disease pattern in poultry with special emphasis on parasites and their methods of control. Proceeding of the $3^{\text {rd }}$ International Poultry Show and Seminar of World Poultry Science AssociationBangladesh Branch. Dhaka, Bangladesh: BCFCC; 2003. 119-123.

5. Ahmed S, Hamid MA. Status of poultry production and developmen strategy in Bangladesh. In Proc. Workshop on Livestock Development in Bangladesh, Savar, Dhaka, Bangladesh: Bangladesh Livestock Research Institute (BLRI); 1992. p. 132-139.

6. Ali MJ. Current status of veterinary biologics production in Bangladesh and their quality control. Proceedings of the BSVER symposium held on July 28, 1994 at NIPSOM auditorium, Mohakali, Dhaka, Bangladesh; 1994.

7. Chanie M, Neqash T and Tilahan SB. Occurrence of concurrent infectious diseases in broiler chickens is a threat to commercial poultry farms in Central Ethiopia. Trop Anim Health Prod. 2009;41(7):1309-1317.

8. Islam MM, Hossain MM, Haider MG, et al. Seroprevalence and pathological study of Salmonella infections in layer chickens and isolationof causal agents. In Proceedings of the $5^{\text {th }}$ International Poultry show and seminar, Sher-e-Bangla Nagar, Dhaka, Bangladesh: China Friendship Conference Centre (CFCC); 2007. p. 9-15.
9. Haider MG, Chowdhury EH, Khan MAHNA, et al. Experimental pathogenesis of pullorum disease with the local isolate of Salmonella enterica serovar. enterica subspecies pullorum in pullets in Bangladesh. Korean J of Poul Sci. 2008;35:341-350.

10. Yunus AW, Nasir MK, Aziz T, et al. Prevalence of poultry diseases in district chakwal and their interaction with mycotoxicosis: Effects of season and feed. J Anim Plant Sci. 2009;19(1):1-5.

11. Jones TC, Hunt RD, Kimg NW. Veterinary Pathology. In: Williams, et al. editors. 6th ed. A Waverly Company; 1996. p. 1024-1041.

12. Khan CM. The Merck Veterinary Manual. 10th ed. USA: Merck Sharp \& Dohme Corporation; 2000. p. 501-524.

13. Harrigan WF. Laboratory methods in food microbiology. New York: USA: Academic Press; 1998. p. 34-35.

14. Bhattacharjee PS, Kundu RL, Biswas RK, et al. Retrospective analysis of chicken diseases diagnosed at the central disease investigation laboratory, Dhaka. Bang Vet J. 1996;30:105-113.

15. Islam MR, Khan MAHNA, Das PM, et al. Poultry diseases diagnosed at necropsy in 1997 and 1998 on the Department of Pathology, Bangladesh Agricultural University, Mymensingh. Proceedings of the fifth BSVER Annual Scientific Conference, Mymensingh, Bangladesh: Bangladesh Agricultural University,

16. Talha AFSM, Hossain MM, Chowdhury EH, et al. Poultry diseases occurring in Mymensingh district of Bangladesh. Bang Vet. 2001;18(1):2023.

17. Islam MR, Das BC, Hossain KH, et al. A study on the occurrence of poultry disease in Sylhet Region of Bangladesh. Int J Poul Sci. 2003;2(5):354 356.

18. Islam MN, Rashid SMH, Hoque MF, et al. Pathogenicity of IBDV related to outbreaks in the vaccinated flocks and the causes of vaccination failure. J Innov Devel Str. 2008;2(3):22-30.

19. Saleque MA. Pattern of poultry diseases in breeding farm and small poultry units in Bangladesh. Proceeding of the 3rd international poultry show and seminar of world poultry science association-Bangladesh Branch. Dhaka, USA: BCFCC; 2003. p. 133-140.

20. Hoque MM, Omar AR, Chong LK, et al. Pathogenicity of Sspl-positive infectious bursal disease virus and molecular characterization of the hypervariable region. Avian Pathol. 2001;30(4):369-380.

21. Godwin AL. Common cases of vaccine failure in developing countries with special reference to Srilanka. Proceeding of the 2nd International Poultry Show and Seminar of World Poultry Science AssociationBangladesh BranchDhaka, Bangladesh: IDB Bhaban; 2001. p. 101-104.

22. Naik BMC, Babu YH, Mamatha GS. The immunomodulatory role of calf thymus extract in humoral and cell mediated immune response in chicken vaccinated against New Castle disease virus. Int J Poul Sci. 2005;4:580583

23. Rahman MS, Rabbani MG, Uddin MJ, et al. Prevalence of avian influenza and Newcastle disease viruses in poultry in selected areas of Bangladesh using rapid antigen detection Kit. Arc Cl Microbiol. 2012;3(1):3.

24. Giasuddin M, Sil BK, Alam J, et al. Prevalence of poultry diseases in Bangladesh. Online J Biol Sci. 2002;2(4):212-213.

25. Rahman MA. Diseases profile with pathogenicity and drug sensitivity of salmonellosis, colibacillosis and pasteurellosis in commercial chickens. MS Thesis. Department of Medicine, Mymensingh, Bangladesh: Bangladesh Agricultural University; 2003. 71 p.

26. Hossain MK, Ahmed M, Kabir H, et al. Poultry diseases at Rajshahi in Bangladesh. J Ani Vet Adv. 2004;3(10):657-659. 
27. Barua H, Biswas PK, Olsen KE, et al. Prevalence and characterization of motile Salmonella in commercial layer poultry farms in Bangladesh. PLoS One. 2012;7(4):e35914

28. Rahman MM, Das PM, Bari ASM, et al. Pathological investigation of diseases of broilers in some farms of Mymensingh. J Ani Vet Adv. 2003;2(12):660-665.

29. Abbas G, Khan $\mathrm{SH}$, Hassan M, et al. Incidence of poultry diseases in different seasons in Khushab district, Pakistan. $J$ Adv Vet Ani Res. 2015;2(2):141-145.

30. Rashid $\mathrm{MH}$, Xue $\mathrm{C}$, Islam $\mathrm{MR}$, et al. A longitudinal study on the incidence of mortality of infectious diseases of commercial layer birds in Bangladesh. Prev Vet Med. 2013;109(3-4):354-358.

31. Mushi EZ, Binta MG, Chabo RG, et al. Escherichia coli infections in chicken broilers in Sebele, Gaborne, Botswana. Res J Poult Sci. 2008;2(2):29-34.

32. Nicole L, Musangu N, Gabriel B, et al. Retrospective study of Escherichia coli in broilers subjected to postmortem examination and antibiotic resistance of isolates in Trinidad. Avian Dis. 2000;44(1):155-160.
33. Islam A, Trisha AA, Das $\mathrm{M}$, et al. Retrospective study of some poultry diseases at gaibandha district in Bangladesh. Bang J Vet Med. 2009;7(1):239-247.

34. Jindal N, Mahajan NK, Mittal D, et al. Some epidemiological studies on infectious bursal disease in broiler chickens in parts of Haryana. Ind Int $J$ of Poult Sci. 2004;7:478-482.

35. Saif EM, Aly M, Ajit AAA El, et al. Epidemiological studies on Gumboro disease in upper Egypt. Vet Med J. 2000;42(84):223-241.

36. Mukhtar M, Awais MM, Anwar MI, et al. Seroprevalence of Mycoplasma gallisepticum among commercial layers in Faisalabad, Pakistan. J Basic and App Sci. 2012;8:183-186.

37. Alexander DJ. Newcastle disease, other avian paramyxoviruses, and pneumovirus infections. In: Saif Y, et al. editors. Diseases Poultry. 11th ed. Ames, USA: Iowa State University Press; 2003. p. 63-99.

38. Biswas PK, Biswas D, Ahmed S, et al. A longitudinal study of the incidence of major endemic and epidemic diseases affecting semi-scavenging chickens reared under the Participatory Livestock Development Project areas in Bangladesh. Avian Pathol. 2005;34(4):303-312. 